\title{
Differential sensitivity of one-cell and two-cell rabbit embryos to sodium chloride and total osmolarity during culture into blastocysts
}

\author{
J. Li and R. H. Foote* \\ Department of Animal Science, Cornell University, Ithaca, NY 14853-4801, USA
}

\begin{abstract}
One-cell or two-cell rabbit embryos were cultured in protein-free media with various $\mathrm{NaCl}$ concentrations and osmolarity to determine relative sensitivity of embryos to changes in media composition. Embryos from replicates of donor rabbits were distributed randomly across treatments and cultured at $39^{\circ} \mathrm{C}$. Zygotes were cultured in Expts $1,2 \mathrm{~A}$ and B, and 3, and two-cell embryos were cultured in Expts 4A and 4B. In Expt 1, blastocyst formation and number of cells were highest $(P<0.05)$ in the control medium with $93 \mathrm{mmol} \mathrm{NaCl} \mathrm{l}^{-1}$ (270 mosmols) compared with media containing 63 and $116 \mathrm{mmol} \mathrm{NaCl}^{-1}$ (220 and 316 mosmols). In Expt 2, embryos were cultured in media with 70 or $93 \mathrm{mmol} \mathrm{NaCl} \mathrm{l}^{-1}$, varying in osmolarity from 250 to 320 mosmols by adding sorbitol. In media with $70 \mathrm{mmol}$ $\mathrm{NaCl} 1^{-1}$ and osmolarities of 250,280 and 300 mosmols, there were 41,56 and $50 \%$ expanded blastocysts, respectively $(P<0.05)$. With $93 \mathrm{mmol} \mathrm{NaCl} \mathrm{l}^{-1}$ and osmolarities of 270,293 and 320 mosmols, embryos developed into 37,53 and $27 \%$ expanded blastocysts, respectively, $(P<0.05)$. In Expts $3 \mathrm{~A}$ and $3 \mathrm{~B}$ and $4 \mathrm{~A}$ and $4 \mathrm{~B}$, the osmolarity of the medium was maintained at 270 mosmols by adding sorbitol to media containing 40 or $60 \mathrm{mmol}$ $\mathrm{NaCl} \mathrm{l}^{-1}$, and other components were reduced in media containing 100 and $116 \mathrm{mmol}$ $\mathrm{NaCl} \mathrm{I}^{-1}$ to compensate for the higher $\mathrm{NaCl}$. Zygote development into blastocysts was greatly suppressed $(P<0.05)$ in media with $40,60,100$ and $116 \mathrm{~mm} \mathrm{NaCl}^{-1}$, compared with the control ( $93 \mathrm{mmol} \mathrm{NaCl} \mathrm{l^{-1 }}$ ), whereas development of two-cell embryos into blastocysts was much less affected. These results appear to reflect a direct sodium chloride as well as osmolarity effect on embryo development; and zygotes are much more sensitive to these effects than are two-cell embryos.
\end{abstract}

\section{Introduction}

When embryos are cultured in a chemically defined protein-free medium fewer blastocysts with fewer blastomeres are formed compared with blastocysts developed in vivo. The causes of these differences are unknown. The ionic composition of embryo culture media has usually been derived from media developed for culture of somatic cells. These media contain a relatively high $\mathrm{NaCl}$ concentration, and $\mathrm{NaCl}$ is a major component of oviduct fluid (David et al., 1969; Iritani et al., 1971; Borland et al., 1977; Dickens and Leese, 1994). The $\mathrm{NaCl}$ $\left(\mathrm{Na}^{+} \mathrm{Cl}^{-}\right)$contributes to the osmolarity of cells and creates electrical potentials across cell membranes, which are important in oocyte maturation and embryo growth (Cross, 1973; Roblero et al., 1976). The $\mathrm{Na}^{+}$gradient across the cell membrane of mouse embryos is required for amino acid transport (Borland and Tasca, 1974, 1975; Dizio and Tasca, 1977), and an exogenous source of amino acids is required for blastocyst formation in rabbits (Kane and Foote, 1970).

Lawitts and Biggers $(1991,1992)$ investigated ionic composition of simple embryo culture media and found that altering

*Correspondence:

Received 24 April 1996 several components, such as $\mathrm{Na}^{+}$and $\mathrm{K}^{+}$, overcame the two-cell block in culturing mouse embryos. Reduction of the $\mathrm{Na}^{+}$concentration in this modified medium resulted in fully functional blastocysts from oocytes fertilized in vitro (Summers et al., 1995). Anbari and Schultz (1993) and Ho et al. (1994) have shown that the pattern of RNA and protein synthesis in mouse embryos cultured in media with reduced $\mathrm{NaCl}$ resemble more closely synthetic patterns of embryos grown in vivo. Rabbit embryos grow much faster than mouse embryos and the concentration of $\mathrm{NaCl}$ may play an important role in rabbit embryo culture (Li and Foote, 1995).

Osmolarity of media, to which $\mathrm{NaCl}$ is a major contributor, has been the focus of several studies. Brinster (1965) reported that the optimal osmolarity for developing mouse embryos was $276 \mathrm{mOsm}$, considerably lower than the normal body fluid value of about $306 \mathrm{mOsm}$. Whitten and Biggers (1968) obtained most blastocysts from mouse zygotes in a defined medium with a calculated osmolarity of $256 \mathrm{mOsm}$. Maurer et al. (1970) found a higher rate of blastulation of rabbit embryos cultured in media with an osmolarity of $256 \mathrm{mOsm}$ than in media at $310 \mathrm{mOsm}$. Other studies indicated that the optimum for rabbit embryo culture media was about 270 mosmols (Naglee et al., 1969; Li and Foote, 1995). 
The relative importance of osmotic changes and $\mathrm{NaCl}$ concentration on embryo development is not clear, and many studies have involved culture of a mixture of one-cell and two-cell embryos. The objectives of the present study were to examine the effects of both $\mathrm{Na}^{+} \mathrm{Cl}^{-}$and osmolarity changes on rabbit embryo development in a defined protein-free medium, and to determine whether there was a differential sensitivity of one-cell versus two-cell rabbit embryos to these changes, as reported for the mouse.

\section{Materials and Methods}

\section{Animals and embryos}

Dutch rabbits were superovulated with $\mathrm{FSH}$ and $\mathrm{LH}$ (Vetrepharm, London, Ontario) by a standard schedule (Kennelly and Foote, 1965) and inseminated at the time of LH injection. In Expts 1, 2 and 3, one-cell embryos were collected $19 \mathrm{~h}$ after LH injection by flushing oviducts with phosphatebuffered saline containing $0.1 \%$ polyvinyl alcohol. The embryos were cultured for $72 \mathrm{~h}$ in Expt 1 , and $62 \mathrm{~h}$ in Expts 2 and 3 , the latter to evaluate development rate more critically. The one-cell 'embryos' or zygotes that did not cleave during the first $24 \mathrm{~h}$ of culture were considered to be unfertilized oocytes. In Expts $4 \mathrm{~A}$ and $4 \mathrm{~B}$, two-cell embryos were collected $24 \mathrm{~h}$ after $\mathrm{LH}$ injection by flushing the oviducts and they were cultured for $57 \mathrm{~h}$, so the total elapsed time from LH injection to final evaluation was the same in Expts 2-4. All culturing was done at $39^{\circ} \mathrm{C}$, the approximate body temperature of the rabbit.

\section{Media and culture}

A special macromolecule-free RD medium (RPMI 1640 with DMEM, I:1) was prepared by Gibco BRL (Life Technologies, Grand island, NY). The experimental medium contained no glucose, glycine or inositol and $25 \mathrm{mmol}$ of $\mathrm{NaCl} \mathrm{l}^{-1}$. The medium was stored at $5^{\circ} \mathrm{C}$ before use and at the time of use $8 \mathrm{mmol}$ glucose $\mathrm{I}^{-1}, 34 \mathrm{mmol} \mathrm{NaHCO}_{3} \mathrm{1}^{-1}, 0.5 \mathrm{mmol}$ glycine $1^{-1}$ and $0.5 \mathrm{mmol}$ inositol $1^{-1}$ were added, so that these were constant in all experiments. The other components of the control RD medium were the same as those described by Carney and Foote (1991) and Li and Foote (1995). The control culture medium, with $\mathrm{NaCl}$ added to a final concentration of $93 \mathrm{mmol} \mathrm{NaCl} \mathrm{l}^{-1}$, had an osmolarity of 270 mosmol. Osmolarity of the experimental media and $\mathrm{NaCl}$ concentration were varied, as indicated in the description of each experiment. Every batch of media was checked by osmometry for concurrence with the expected osmolarity.

Media for culturing embryos were equilibrated overnight in an atmosphere of $5 \% \mathrm{CO}_{2}: 95 \%$ humidified air. Approximately 5 to 15 embryos were added to each $120 \mu$ l droplet of media in $35 \mathrm{~mm}$ Falcon petri dishes and cultured under $4 \mathrm{ml}$ Dow Corning Medical 360 Fluid (Dow Corning, Midland, $\mathrm{MI})$ at $39^{\circ} \mathrm{C}$ in an atmosphere of $5 \% \mathrm{CO}_{2}: 95 \%$ humidified air.

In Expt 1, one-cell embryos were cultured in the special medium with different osmolarities $(220,250,270,300$ and
316 mOsmols) produced by $\mathrm{NaCl}$ concentrations from 63 to $116 \mathrm{mmol} \mathrm{l}^{-1}$. Embryo development was evaluated at $72 \mathrm{~h}$ of culture. Stage of development and cell counts were the criteria used in evaluating experimental effects. The cell counts were made on blastocysts stained with Hoechst dye 33342 by the procedure described by Pursel et al. (1985).

In Expts $2 \mathrm{~A}$ and $2 \mathrm{~B}$ effects of various osmolarities of sorbitol on embryo development, while maintaining a constant $\mathrm{NaCl}$ concentration of either 70 or $93 \mathrm{mmol} \mathrm{l}^{-1}$, were studied. In Expt $2 \mathrm{~A}$, one-cell embryos were cultured in a $70 \mathrm{mmol} \mathrm{NaCl}$ $1^{-1}$ medium with sorbitol added at concentrations of $0,7.5$ and $11.2 \mathrm{mg} \mathrm{ml}^{-1}$ (osmolarity: 250, 280 and $300 \mathrm{mOsmols,}$ respectively). Embryos cultured in the medium with $93 \mathrm{mmol}$ $\mathrm{NaCl} \mathrm{L^{-1 }}$ and an osmolarity of $270 \mathrm{mOsmol}$ served as a

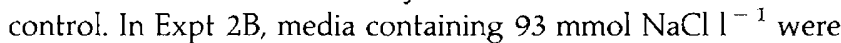
prepared with osmolarities of 270,293 and $320 \mathrm{mOsmols}$ by adding sorbitol at concentrations of $0,3.7$ and $8.5 \mathrm{mg} \mathrm{ml}^{-1}$, respectively. The proportion of embryos developing to different stages was recorded after $62 \mathrm{~h}$ of culture.

In Expts $3 \mathrm{~A}$ and $3 \mathrm{~B}$, effects of $\mathrm{NaCl}$ concentrations ranging from $40 \mathrm{mmol} \mathrm{I}^{-1}$ to $116 \mathrm{mmol} \mathrm{l}^{-1}$, while keeping the osmolarity of the culture medium constant, on one-cell embryo growth were investigated. The total osmolarity of the medium was maintained at 270 mosmols by adding $17 \mathrm{mg}$ sorbitol $\mathrm{ml}^{-1}$ to the $40 \mathrm{mmol} \mathrm{NaCl} \mathrm{l}^{-1}$ medium and $11 \mathrm{mg} \mathrm{ml}^{-1}$ to the $60 \mathrm{mmol} \mathrm{NaCl} 1^{-1}$ treatment. An osmolarity of 270 mosmols was maintained with the treatments containing 100 and $116 \mathrm{mmol} \mathrm{NaCl}{ }^{-1}$, by reducing the other components in the RD medium appropriately before the addition of $\mathrm{NaCl}$. This experiment was divided into two parts, $A$ and $B$, to limit the number of treatments so that a substantial number of embryos from each donor would be available to assign randomly to each treatment. In Expt $3 \mathrm{~A}$, the $\mathrm{NaCl}$ concentrations were 40,60 and $93 \mathrm{mmol} \mathrm{l}^{-1}$ and in Expt 3B, the $\mathrm{NaCl}$ concentrations were 93,100 and $116 \mathrm{mmol}^{-1}$. The proportion of one-cell embryos developing to different stages was recorded at $62 \mathrm{~h}$ of culture to provide a more critical evaluation of the rate of development into blastocysts.

With the marked differences obtained in Expt 3, it was feasible to use the same experimental design in Expts $4 \mathrm{~A}$ and $4 \mathrm{~B}$ to test the effects with two-cell embryos. In addition, development of the embryos was recorded at $57 \mathrm{~h}$ of culture, which was the same elapsed time from $\mathrm{LH}$ injection as in Expt 3 in which one-cell embryos were collected $5 \mathrm{~h}$ sooner than the two-cell embryos.

\section{Statistical analysis}

A randomized complete block design was used in all experiments, with the embryos from each donor representing one complete block. Embryos from each donor were divided equally and randomly assigned to treatment groups. A twoway analysis of variance was performed, using the general linear models procedure of the Statistical Analysis System (SAS Institute, Cary, NC). The arcsine transformation of the proportion of blastocysts formed in each droplet was used for the percentage data analysis. When analysis of variance indicated significant mean differences, these were compared using Duncan's new multiple range test. 
Table 1. Effect of increasing $\mathrm{NaCl}$ and osmolarity on one-cell rabbit embryos cultured in $\mathrm{RD}$ medium for $72 \mathrm{~h}$ (Expt 1)

\begin{tabular}{|c|c|c|c|c|c|c|c|}
\hline \multirow{3}{*}{$\begin{array}{l}\mathrm{NaCl} \\
\left(\mathrm{mmol} \mathrm{l}^{-1}\right)\end{array}$} & \multirow{3}{*}{$\begin{array}{l}\text { Osmolarity } \\
\text { (mosmol) }\end{array}$} & \multirow{3}{*}{$\begin{array}{l}\text { Number of } \\
\text { zygotes* }\end{array}$} & \multicolumn{5}{|c|}{ Number (\%) of embryos at each stage } \\
\hline & & & \multirow{2}{*}{$\begin{array}{l}2-4- \\
\text { cell }\end{array}$} & \multirow[b]{2}{*}{ Morulae } & \multicolumn{3}{|c|}{ Blastocysts } \\
\hline & & & & & Expanded & Hatching & Total \\
\hline 63 & 220 & 38 & 0 & $24^{a}$ & $10^{a}$ & $4^{a}$ & $14(37)^{\mathrm{a}}$ \\
\hline 70 & 250 & 38 & 0 & $19^{a}$ & $13^{a}$ & $6^{a}$ & $19(50)^{\mathrm{b}}$ \\
\hline 93 & 270 & 34 & 0 & $8^{\mathrm{b}}$ & $15^{\mathrm{a}}$ & $11^{\mathrm{b}}$ & $26(76)^{c}$ \\
\hline 106 & 300 & 34 & 0 & $11^{\mathrm{ab}}$ & $14^{\mathrm{a}}$ & $9^{b}$ & $23(68)^{\mathrm{c}}$ \\
\hline \multirow[t]{2}{*}{116} & 316 & 34 & 0 & $12^{\mathrm{ab}}$ & $19^{a}$ & $3^{\mathrm{a}}$ & $22(65)^{\mathrm{c}}$ \\
\hline & & $\begin{array}{l}\text { Number of } \\
\text { blastocysts }\end{array}$ & $\begin{array}{l}\text { Number of } \\
\text { cells }\end{array}$ & & & & \\
\hline 63 & 220 & 13 & $150^{\mathrm{a}}$ & & & & \\
\hline 70 & 250 & 10 & $190^{\mathrm{b}}$ & & & & \\
\hline 93 & 270 & 14 & $200^{\mathrm{b}}$ & & & & \\
\hline 106 & 300 & 12 & $178^{\mathrm{b}}$ & & & & \\
\hline 116 & 316 & 15 & $132^{\mathrm{a}}$ & & & & \\
\hline
\end{tabular}

*Zygotes were obtained from 12 donor rabbits.

a.b.c Means within columns with different superscripts are significantly different $(P<0.05)$.

Table 2. Effect of varying osmolarity with sorbitol on one-cell rabbit embryos cultured in RD medium for $62 \mathrm{~h}$ (Expts $2 \mathrm{~A}$ and $2 \mathrm{~B}$ )

\begin{tabular}{|c|c|c|c|c|c|c|c|c|}
\hline \multirow{3}{*}{$\begin{array}{l}\mathrm{NaCl} \\
\left(\mathrm{mmol} \mathrm{l}^{-1}\right)\end{array}$} & \multirow{3}{*}{$\begin{array}{l}\text { Osmolarity } \\
\text { (mosmol) }\end{array}$} & \multirow{3}{*}{$\begin{array}{l}\text { Sorbitol } \\
\left(\mathrm{mg} \mathrm{ml}^{-1}\right)\end{array}$} & \multirow{3}{*}{$\begin{array}{l}\text { Number of } \\
\text { zygotes* }\end{array}$} & \multicolumn{5}{|c|}{ Number $(\%)$ of embryos at each stage } \\
\hline & & & & \multirow{2}{*}{$\begin{array}{l}2-4- \\
\text { cell }\end{array}$} & \multirow[b]{2}{*}{ Morulae } & \multicolumn{3}{|c|}{ Blastocysts } \\
\hline & & & & & & Early & Expanded & Total \\
\hline \multicolumn{9}{|c|}{ Experiment $\mathrm{A}$} \\
\hline 93 & 270 & 0 & 31 & 0 & $4^{a}$ & $9^{a}$ & $18(58)^{\mathrm{a}}$ & $27(87)^{\mathrm{a}}$ \\
\hline 70 & 250 & 0 & 29 & 0 & $9^{a}$ & $8^{a}$ & $12(41)^{\mathrm{b}}$ & $20(69)^{b}$ \\
\hline 70 & 280 & 7.5 & 34 & 0 & $11^{\mathrm{a}}$ & $4^{a}$ & $19(56)^{a}$ & $23(68)^{b}$ \\
\hline 70 & 300 & 11.2 & 36 & 0 & $11^{a}$ & $7^{a}$ & $18(50)^{a}$ & $25(69)^{\mathrm{b}}$ \\
\hline \multicolumn{9}{|c|}{ Experiment B } \\
\hline 93 & 270 & 0 & 51 & 0 & $20^{\mathrm{b}}$ & $12^{\mathrm{a}}$ & $19(37)^{a}$ & $31(61)^{a}$ \\
\hline 93 & 293 & 3.7 & 54 & 0 & $13^{\mathrm{a}}$ & $12^{a}$ & $2 \dot{9}(53)^{\mathrm{b}}$ & $41(76)^{b}$ \\
\hline 93 & 320 & 8.5 & 49 & 0 & $29^{b}$ & $7^{\mathrm{a}}$ & $13(27)^{a}$ & $20(41)^{\circ}$ \\
\hline
\end{tabular}

*Zygotes were obtained from 8 and 12 donor rabbits in Expts A and B.

a.b.c. Means within columns with different superscripts are significantly different $(P<0.05)$.

\section{Results}

In Expt 1 (Table 1), optimal development of one-cell embryos was in a medium with $93 \mathrm{mmol} \mathrm{NaCl} \mathrm{I}^{-1}$ and $270 \mathrm{mOsmols,}$ and hatching was lower in media containing lower or higher $\mathrm{NaCl}$ concentrations $(P<0.05)$. In addition, the blastocysts formed in the media with 70,93 and $106 \mathrm{mmol} \mathrm{NaCl} \mathrm{l}^{-1}$ contained more cells $(P<0.05)$ than did blastocysts cultured in media with 63 or $116 \mathrm{mmol} \mathrm{NaCl}^{-1}$.

In Expt 2 (Table 2), zygotes cultured for $62 \mathrm{~h}$ did not have time to hatch, in contrast to Expt 1. Expanded blastocyst development in Expt 2A was lower in the $250 \mathrm{mOsmol}$ group and total blastocyst development was highest in the $270 \mathrm{mOsmol}$ control group with $93 \mathrm{mmol} \mathrm{NaCl} \mathrm{l}^{-1}(P<0.05)$. Embryos cultured in the medium with $93 \mathrm{mmol} \mathrm{NaCl}^{-1}$ and an osmolarity of $293 \mathrm{mOsmols}$ (Expt 2B) developed into significantly more expanded and total blastocysts than in other groups $(P<0.05)$.

In Expt 3 (Table 3), one-cell embryos were cultured in media with various $\mathrm{NaCl}$ concentrations and constant osmolarity. In Expt 3A, the embryos cultured in the medium with $93 \mathrm{mmol}$ $\mathrm{NaCl} 1^{-1}$ developed into significantly more blastocysts $(P<0.05)$ than did the embryos cultured in the media with $40 \mathrm{mmol} \mathrm{I}^{-1}$ and $60 \mathrm{mmol} \mathrm{I}^{-1} \mathrm{NaCl}$. Likewise, in Expt 4B, the 
Table 3. Test of $\mathrm{NaCl}$ concentration on one-cell rabbit embryos with osmolarity maintained at 270 mosmols in RD medium for $62 \mathrm{~h}$ (Expts $3 \mathrm{~A}$ and $3 \mathrm{~B}$ )

\begin{tabular}{|c|c|c|c|c|c|c|c|}
\hline \multirow{3}{*}{$\begin{array}{l}\mathrm{NaCl}^{*} \\
\left(\mathrm{mmol} \mathrm{l}^{-1}\right)\end{array}$} & \multirow{3}{*}{$\begin{array}{c}\text { Osmolarity } \\
\text { (mosmol) }\end{array}$} & \multirow{3}{*}{$\begin{array}{l}\text { Number of } \\
\text { zygotes }^{\dagger}\end{array}$} & \multicolumn{5}{|c|}{ Number $(\%)$ of embryos at each stage } \\
\hline & & & \multirow{2}{*}{$\begin{array}{c}2-4- \\
\text { cell }\end{array}$} & \multirow[b]{2}{*}{ Morulae } & \multicolumn{3}{|c|}{ Blastocysts } \\
\hline & & & & & Early & Expanded & Total \\
\hline \multicolumn{8}{|c|}{ Experiment $\mathrm{A}$} \\
\hline 40 & 270 & 28 & 1 & $27^{\mathrm{a}}$ & $0^{a}$ & $0^{a}$ & $0 \quad(0)^{a}$ \\
\hline 60 & 270 & 27 & 0 & $16^{\mathrm{a}}$ & $6^{\mathrm{b}}$ & $5^{b}$ & $11(41)^{\mathrm{b}}$ \\
\hline 93 & 270 & 28 & 0 & $3^{b}$ & $6^{\mathrm{b}}$ & $19^{\circ}$ & $25(89)^{\circ}$ \\
\hline \multicolumn{8}{|c|}{ Experiment B } \\
\hline 93 & 270 & 40 & 0 & $0^{a}$ & $7^{a}$ & $33^{\mathrm{a}}$ & $40(100)^{2}$ \\
\hline 100 & 270 & 39 & 0 & $11^{b}$ & $11^{a}$ & $17^{b}$ & $28(71)^{b}$ \\
\hline 116 & 270 & 38 & 2 & $20^{b}$ & $5^{a}$ & $11^{\mathrm{c}}$ & $16(42)^{\circ}$ \\
\hline
\end{tabular}

*The total osmolarity of the medium was maintained at 270 mosmols by adding $17 \mathrm{mg}$ sorbitol $\mathrm{ml}^{-1}$ to the $40 \mathrm{mmol} \mathrm{NaCl}^{-1}$ treatment and $11 \mathrm{mg} \mathrm{ml}^{-1}$ to the $60 \mathrm{mmol} \mathrm{NaCl} \mathrm{I}^{-1}$ treatment, and other components of the $\mathrm{RD}$ medium were reduced to compensate for adding more $\mathrm{NaCl}$ to the 100 and 116 mmolar $\mathrm{NaCl}$ treatments. ${ }^{\dagger} Z$ ygotes were obtained from six and seven donor rabbits in Expts $A$ and $B$.

${ }_{\text {a.b.c }}$ Means within columns with different superscripts are significantly different $(P<0.05)$.

Table 4. Test of $\mathrm{NaCl}$ concentration on two-cell rabbit embryos with osmolarity maintained at 270 mosmols in RD medium for $57 \mathrm{~h}$ (Expts $4 \mathrm{~A}$ and $4 \mathrm{~B}$ )

\begin{tabular}{|c|c|c|c|c|c|c|c|}
\hline \multirow{3}{*}{$\begin{array}{l}\mathrm{NaCl}^{*} \\
\left(\mathrm{mmol} 1^{-1}\right)\end{array}$} & \multirow{3}{*}{$\begin{array}{c}\text { Osmolarity } \\
\text { (mosmol) }\end{array}$} & \multirow{3}{*}{$\begin{array}{c}\text { Number of } \\
\text { two-cell } \\
\text { embryos }^{\dagger}\end{array}$} & \multicolumn{5}{|c|}{ Number $(\%)$ of embryos at each stage } \\
\hline & & & \multirow{2}{*}{$\begin{array}{l}2-4- \\
\text { cell }\end{array}$} & \multirow[b]{2}{*}{ Morulae } & \multicolumn{3}{|c|}{ Blastocysts } \\
\hline & & & & & Early & Expanded & Total \\
\hline \multicolumn{8}{|c|}{ Experiment $\mathrm{A}$} \\
\hline 40 & 270 & 29 & 0 & $14^{\mathrm{a}}$ & $3^{a}$ & $I 2^{\mathrm{a}}$ & $15(52)^{a}$ \\
\hline 60 & 270 & 29 & 0 & $3^{\mathrm{b}}$ & $5^{\mathrm{a}}$ & $21^{\mathrm{b}}$ & $26(90)^{b}$ \\
\hline 93 & 270 & 28 & 0 & $5^{b}$ & $6^{\mathrm{a}}$ & $17^{\mathrm{b}}$ & $23(82)^{b}$ \\
\hline \multicolumn{8}{|c|}{ Experiment B } \\
\hline 93 & 270 & 30 & 0 & $7^{\mathrm{a}}$ & $4^{\mathrm{a}}$ & $19^{\mathrm{a}}$ & $23(77)^{\mathrm{a}}$ \\
\hline 100 & 270 & 28 & 0 & $6^{a}$ & $5^{a}$ & $17^{\mathrm{a}}$ & $22(79)^{a}$ \\
\hline 116 & 270 & 30 & 0 & $16^{b}$ & $5^{a}$ & $9^{b}$ & $14(47)^{\mathrm{b}}$ \\
\hline
\end{tabular}

medium with $93 \mathrm{mmol} \mathrm{NaCl} \mathrm{l}^{-1}$ supported greater development into blastocysts than did the media with higher $\mathrm{NaCl}$ concentrations $(P<0.05)$.

In Expt $4 \mathrm{~A}$ (Table 4), the medium with $93 \mathrm{mmol} \mathrm{NaCl} 1^{-1}$ promoted better growth of two-cell embryos than did the

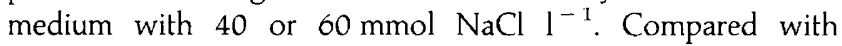
one-cell embryos (Expt 3), two-cell embryos were more able to tolerate lower $\mathrm{NaCl}$ concentrations in the culture medium (Fig. 1). The two-cell embryos were more similar to one-cell embryos in responding to higher $\mathrm{NaCl}$ concentrations in the culture medium, although the actual percentage decrease with two-cell embryos of 77 to $47 \%$ blastocysts in Expt $4 \mathrm{~B}$ was less than the decrease from 100 to $42 \%$ blastocysts when one-cell embryos were cultured in comparable media in Expt 3B.

\section{Discussion}

Mammalian preimplantation embryos developing within the protected environment of the female reproductive tract are provided with all necessary nutrients for early embryo growth and a system for removing wastes. Embryos cultured in vitro must obtain all nutrients from the culture medium once the initial store in the oocyte is depleted, and also must be protected from potential toxic elements. Preimplantation rabbit embryos grow rapidly. Thus, for example, nutrient requirements may be greater for rabbit embryos than for the mouse embryos to maintain normal development, protein synthesis, intracellular organelle organization and cell division. While amino acids, vitamins, DNA precursors and glucose provide 


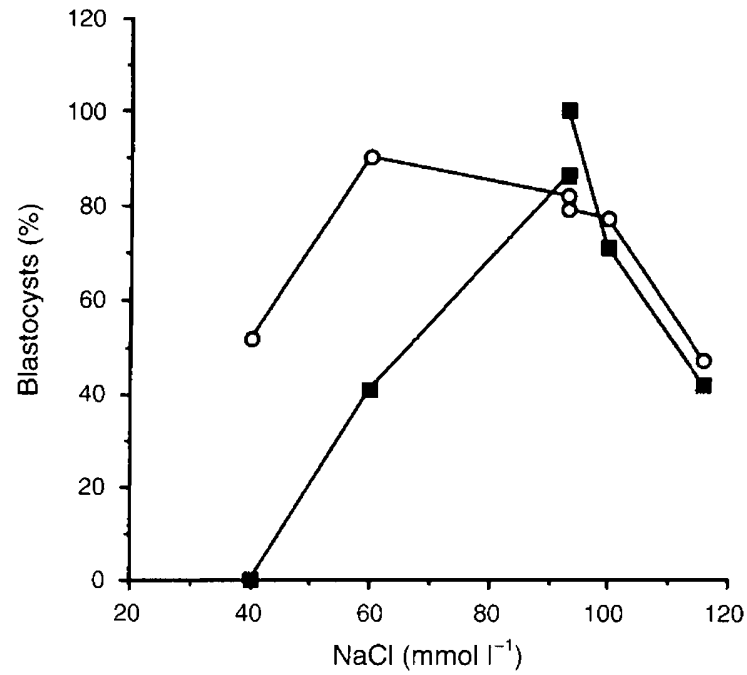

Fig. 1. Comparison of blastocyst development from ( $\square$ ) one-cell and (O) two-cell embryos cultured in $R D$ medium with $\mathrm{NaCl}$ concentration from 40 to $120 \mathrm{mmol} \mathrm{I}^{-1}$, but with osmolarity constant at $270 \mathrm{mOsmols}$.

materials for embryo growth, salts are also required to maintain normal cell activity, including RNA replication (Ho et al., 1994).

The two-cell culture block of CFI mouse embryos can be overcome by decreasing the $\mathrm{NaCl}$ concentration in the medium (Lawitts and Biggers, 1991; Summers et al., 1995). It is clear that transport of some amino acids and sugars is Na-dependent. The $\mathrm{Na}^{+}$gradient across cell membranes furnishes the energy for this transport (Schultz and Curran, 1970).

Some rabbit embryos can develop in media containing 63 to $116 \mathrm{mmol} \mathrm{NaCl}{ }^{-1}$, with an osmolarity ranging from $220 \mathrm{mOsmol}$ to $316 \mathrm{mOsmol}$, as shown in Expt 1. More embryos became hatching blastocysts composed of more cells when the embryos were cultured in the medium with an osmolarity of $270 \mathrm{mOsmol}$ and a $\mathrm{NaCl}$ concentration of $93 \mathrm{mmol} \mathrm{I}^{-1}$ than in 220 and $316 \mathrm{mOsmol}$ media. The results of Expts 1 and 2 indicated that osmolarity and $\mathrm{NaCl}$ content of the culture medium may affect embryo growth, as differences observed between 250 and 270 mOsmols with $\mathrm{NaCl}$ were not found with $\mathrm{NaCl}$ constant at $70 \mathrm{mmol} \mathrm{1}^{-1}$ and osmolarity altered by sucrose (Expt 2A). However, at a constant $93 \mathrm{mmol} \mathrm{NaCl}{ }^{-1}$, increasing the osmolarity with sucrose to $320 \mathrm{mOsmols}$ decreased the percentage of motile spermatozoa.

On the basis of these results, culture media with different concentrations of $\mathrm{NaCl}$, but with osmolarity held constant at $270 \mathrm{mOsmols}$ were formulated for Expts 3 and 4 . The optimal concentration of $93 \mathrm{mmol} \mathrm{NaCl} 1^{-1}$ in RD culture medium for culture of zygotes was verified as more blastocysts developed at these $\mathrm{NaCl}$ concentrations than in media with lower or higher $\mathrm{NaCl}$ concentrations. There was a striking difference in the sensitivity of the one-cell versus two-cell embryos to changes in $\mathrm{NaCl}$ concentrations. The two-cell rabbit embryos were relatively resistant to the $\mathrm{NaCl}$ effect. For example, in $40 \mathrm{mmol} \mathrm{NaCl} \mathrm{I}{ }^{-1}$ no zygotes became blastocysts, but $52 \%$ of the two-cell embryos became blastocysts in the same medium. Although cultured rabbit zygotes do not have a two-cell block, as occurs in embryos from some strains of mice, transition from the one-cell stage to the two-cell stage was critical for future embryo growth in these experiments. This is consistent with preliminary observations of $\mathrm{Li}$ and Foote (1995).

Rambhatla and Latham (1995) found differences between strains of mice in ability to cleave beyond the two-cell stage in the presence of $\alpha$-amanitin. They postulated that different strains may have different supplies of needed precursors in their oocytes. It cannot be ascertained, in the present studies, whether the longer development in vivo provided the two-cell embryos with additional needed precursors for eventual development into blastocysts, or whether other events associated with passing the first cleavage division in vivo facilitated subsequent development.

The results of these studies confirm and extend previous reports on the effects of osmolarity, $\mathrm{NaCl}\left(\mathrm{Na}^{+} \mathrm{Cl}^{-}\right)$or both factors on embryo development in vitro (Brinster, 1965; Whitten and Biggers, 1968; Naglee et al., 1969; Lawitts and Biggers, 1991, 1992; Beckman and Day, 1993; Biggers et al., 1993; $\mathrm{Li}$ and Foote, 1995). The reduction of $\mathrm{NaCl}$ concentration in the medium from 125 to $85 \mathrm{mmol} \mathrm{l}^{-1}$ (Biggers et al., 1993) resulted in intracellular $\mathrm{Na}^{+}$and $\mathrm{K}^{+}$concentrations of cultured mouse embryos resembling more closely intracellular ion concentrations of embryos produced in vivo. Similar reductions of $\mathrm{NaCl}$ in the medium resulted in increased RNA synthesis (Ho ef al., 1994) and protein synthesis (Anbari and Schultz, 1993).

The only compound containing $\mathrm{Na}^{+}$and $\mathrm{Cl}^{-}$that was varied in the present studies was $\mathrm{NaCl}$. However, the $\mathrm{RD}$ medium also contained $34 \mathrm{mmol} \mathrm{NaHCO}_{3} \mathrm{l}^{-1}, 0.5 \mathrm{mmol}$ $\mathrm{NaH}_{2} \mathrm{PO}_{4} \mathrm{I}^{-1}$ and $0.5 \mathrm{mmol}$ sodium pyruvate $1^{-1}$. The sole source of $\mathrm{K}^{+}$was $5.4 \mathrm{mmol} \mathrm{KCl} \mathrm{l}{ }^{-1}$. Other compounds containing $\mathrm{Cl}^{-}$were $0.9 \mathrm{mmol} \mathrm{CaCl} \mathrm{I}^{-1}$ and trace quantities $\left(<1 \mathrm{mmol} \mathrm{I}^{-1}\right.$ total) of the hydrochlorides of vitamins. These experiments were not designed on the large scale necessary to study the concentrations and interactions of $\mathrm{Na}^{+}, \mathrm{K}^{+}$and $\mathrm{Cl}^{-}$, all important in blastocyst formation (Borland et al., 1977; Brison and Leese, 1993; Lawitts and Biggers, 1992; Summers ef al., 1995). However, it is clear from the current study that the concentration of $\mathrm{NaCl}$ in the medium is more important for culturing rabbit zygotes than is often assumed and that many commercially available culture media, such as TCM 199, may have a higher $\mathrm{NaCl}$ content $\left(116 \mathrm{mmol} \mathrm{l}^{-1}\right)$ than is optimal for embryo culture.

It should be noted that the optimal concentration of $\mathrm{NaCl}$ was considerably lower than concentrations found in rabbit oviduct fluid (David et al., 1969; Iritani et al., 1971; Borland et al., 1977; Dickens and Leese, 1994). This finding suggests that other components in oviduct fluid assist the embryo in maintaining intracellular physiological conditions.

From these studies it is concluded that osmolarity of culture media has an important effect on growth and development of rabbit embryos and that a critical component of the media contributing to this effect is the $\mathrm{NaCl}$ concentration. Furthermore, rabbit zygotes are much more sensitive to these effects than are two-cell embryos when cultured to the blastocyst stage in defined protein-free media. These results demonstrate, in a species besides the mouse, the importance of ionic balance in a protein-free medium for culturing zygotes, and the need for caution when comparing the effects of different media supplements in different studies in which the basic ionic components of the media differ. 
The authors thank M. Simkin and M. McArdle for technical assistance and D. Bevins for manuscript preparation. The research was partly funded by NICHD National Cooperative Program on Nonhuman in vitro Fertilization and Preimplantation Development, National Institute of Child Health and Human Development NIH, through Cooperative Agreement HD21939. Dr L. Burkman of Gibco BRL (Grand Island, NY) kindly supplied some of the modified culture media. Vetrepharm, Inc. (London, Ontario) kindly provided the FSH and $\mathrm{LH}$.

\section{References}

Anbari K and Schultz RM (1993) Effect of sodium and betaine in culture media on development and relative rates of protein synthesis in preimplantation mouse embryos in vitro. Molecular Reproduction and Development 35 24-28

Beckmann LS and Day BN (1993) Effects of media $\mathrm{NaCl}$ concentration and osmolarity on the culture of early-stage porcine embryos and the viability of embryos cultured in a selected superior medium Theriogenology 39611-622

Biggers JD, Lawitts JA and Lechene CP (1993) The protective action of betaine on the deleterious effect of $\mathrm{NaCl}$ on preimplantation mouse embryos in vitro. Molecular Reproduction and Development 34 380-390

Borland RM and Tasca RJ (1974) Activation of a $\mathrm{Na}^{+}$-dependent amino acid transport system in preimplantation mouse embryos Developmental Biology $36 \quad 169-174$

Borland RM and Tasca RJ (1975) $\mathrm{Na}^{+}$-dependent amino acid transport in preimplantation mouse embryos Developmental Biology 46 192-201

Borland RM, Hazra S, Biggers JD and Lechene CP (1977) The elemental composition of the environment of the gametes and preimplantation embryo during initiation of pregnancy Biology of Reproduction 16 147-157

Brinster RL (1965) Studies on the development of mouse embryos in vitro. Effect of osmolarity and hydrogen ion concentration Joumal of Experimental Zoology 158 49-58

Brison DR and Leese HJ (1993) Role of chloride transport in the development of the rat blastocyst Biology of Reproduction 48 692-702

Carney EW and Foote RH (1991) Improved development of rabbit one-cell embryos to the hatching blastocyst stage by culture in a defined protein-free culture medium Journal of Reproduction and Fertility 91 113-123

Cross MH (1973) Active sodium and chloride transport across the rabbit blastocoele wall Biology of Reproduction 8 566-575

David A, Brackett BG, Garcia C-R and Mastroianni L, Jr (1969) Composition of rabbit oviduct fluid in ligated segments of the Fallopian tube journal of Reproduction and Fertility 19 285-289

Dickens CJ and Leese HJ (1994) The regulation of rabbit oviduct fluid formation Journal of Reproduction and Fertility $100577-581$
Dizio SM and Tasca RJ (1977) Sodium-dependent amino acid transport in preimplantation mouse embryos. III. Na-K-ATPase-linked mechanism in blastocysts Developmental Biology 59 198-205

Ho Y, Doherty AS and Schultz RM (1994) Mouse preimplantation embryo development in vitro: effect of sodium concentration in culture media on RNA synthesis and accumulation and gene expression Molecular Reproduction and Development 38 13I-141

Iritani A, Nishikawa Y, Gomes WR and VanDemark NL (1971) Secretion rates and chemical composition of oviduct and uterine fluids in rabbits journal of Animal Science 33 829-835

Kane MT and Foote RH (1970) Culture of two- and four-cell rabbit embryos to the expanding blastocyst stage in synthetic media Proceedings of the Society of Experimental Biology and Medicine $133921-925$

Kennelly IJ and Foote RH (1965) Superovulatory response of pre- and postpubertal rabbits to commercially available gonadotrophins Journal of Reproduction and Fertility 9 177-188

Lawitts JA and Biggers JD (1991) Optimization of mouse embryo culture media using simplex methods Journal of Reproduction and Fertility 91 543-556

Lawitts JA and Biggers JD (1992) Joint effect of sodium chloride, glutamine, and glucose in mouse preimplantation embryo culture media Molecular Reproduction and Development 31 189-194

Li J and Foote RH (1995) Effect of inositol and glycine with increasing sodium chloride and constant osmolality on development of rabbit embryos Journal of Assisted Reproduction and Genetics 12 141-146

Maurer RR, Onuma $\mathrm{H}$ and Foote RH (1970) Viability of cultured and transferred rabbit embryos Journal of Reproduction and Fertility 21 417-422

Naglee DL, Maurer RR and Foote RH (1969) Effect of osmolarity on in vitro development of rabbit embryos in a chemically defined medium Experimental Cell Research 58 331-333

Pursel VG, Wall RJ, Rexroad CE and Brinster RL (1985) A rapid whole-mount staining procedure for nuclei of mammalian embryos Theriogenology 41 1571-1583

Rambhatla L and Latham KE (1995) Strain-specific progression of $\alpha$-amanitintreated mouse embryos beyond the two-cell stage Molecular Reproduction and Development 41 16-19

Roblero L, Biggers JD and Lechene CP (1976) Electron probe analysis of the elemental microenvironment of oviductal mouse embryos Journal of Reproduction and Fertility 46 431-434

Schultz SG and Curran PF (1970) Coupled transport of sodium and organic solutes Physiological Reviews $\mathbf{5 0}$ 637-718

Summers MC, Bhatnagar, Lawitts JA and Biggers JD (1995) Fertilization in vitro of mouse ova from inbred and outbred strains: complete preimplantation embryo development in glucose-supplemented KSOM Biology of Reproduction $5343 I-437$

Whitten WK and Biggers JD (1968) Complete development in vitro of the preimplantation stage of the mouse in a simple chemical defined medium. Journal of Reproduction and Fertility 17 399-441 